\title{
“Apprentis Chercheurs" in Drugs Disorders: A New Concept in Prevention Strategy
}

\author{
Bertrand Nalpas',2, Jérémie Cordonnier ${ }^{3}$, Morgane Le Brass,4, Dominique Donnet-Kamel1 \\ ${ }^{1}$ Department of Scientific Information and Communication, Scientific Mediation Office Inserm, Paris, France \\ ${ }^{2}$ Addiction Treatment Unit, Hôpital Caremeau, Nîmes, France \\ ${ }^{3}$ Association Arbre des Connaissances, Institut Universitaire d'Hématologie, Paris, France \\ ${ }^{4}$ Inserm U944-CNRS UMR 7212, Institut Universitaire d’Hématologie-Hôpital Saint Louis, Paris, France \\ Email: bertrand.nalpas@inserm.fr
}

Received 16 September 2014; revised 12 October 2014; accepted 26 October 2014

Copyright $(2014$ by authors and Scientific Research Publishing Inc.

This work is licensed under the Creative Commons Attribution International License (CC BY).

http://creativecommons.org/licenses/by/4.0/

(c) (1) Open Access

\begin{abstract}
We report a new strategy based on scientific education for sensitizing teenagers to the addictionrelated harms. This strategy is diverted from a program called "Apprentis Chercheurs". Pairs of young adolescents are welcome in research laboratories working on addiction all along the school year. They are fully integrated in the research team and directly participate to the experiments under the supervision of a senior researcher. At the end of the school year, they orally communicate their results to other students of their schools, their teachers, their parents and the research team in a peer-to-peer approach during a scientific conference organized within every participant research center.
\end{abstract}

Keywords

Scientific Education, Addiction, Prevention

\section{Introduction}

Addiction among youth, teens and pre-teens, has been a constant concern for health authorities for many years since it is now accepted that early consumption, at adolescence stage when brain tissue is still developing, is a risk factor of developing dependence in adulthood (Dewit et al., 2000; Hingson et al., 2006; Dawson et al., 2008).

The two main products consumed by young people are alcohol and cannabis. In France, the prevalence of consumption is estimated using several types of surveys: ESCAPAD (Health Survey that governs all young boys and girls between 17 and 20 years old), ESPAD (European school Survey Project on Alcohol and Other Drugs) 
conducted in schools, and Health Barometer conducted on a representative sample of the general population.

According to the 2011 ESCAPAD survey (Spilka \& Le Nézet, 2012), daily smoking concerned $31.5 \%$ of young people, repeated drunkenness $27.8 \%$, and regular cannabis use $6.5 \%$, whereas the corresponding figures in 2008 were $28.9 \%, 25.6 \%$ and $7.3 \%$, respectively (Legleye et al., 2009). Data collected in the 2011 ESPAD survey (Spilka \& Le Nézet, 2011), performed in more than 100000 young people from the EU, showed the same trends when compared to the results of the 2007 survey (ESPAD, 2007).

Repeating investigations demonstrate time variations of prevalence in both decrease and increase directions. The trend between 2005 and 2008 according to the Escapad surveys was a decrease of smoking and cannabis use, associated with an increased frequency of intoxication of binge drinking. Conversely, from 2008 to 2011, smoking and binge drinking increased again while cannabis use decreased. Altogether, these data show that behaviors change quickly, and that experimentation is subject to fads and availability of products. Thus, it is difficult to predict future developments; nevertheless the results obtained so far allow emphasizing that the abandonment of a product is compensated by the attraction to another: the overall problem still remains. This suggests that preventive actions taken so far, based on various tools such as radio spots, video TV, newspapers, mini-conference within schools conducted by scientists, former drinkers, police, lawyers... are not sufficient.

In 2001, the Council of Europe has issued ten recommendations on alcohol consumption among young people, in particular children and teenagers (JOCE, 2001). Recommendation 6 stated that Member States should "increase young people's involvement in youth health-related policies and actions, making full use of the contributions which they can make, especially in the field of information, and encourage specific activities which are initiated, planned, implemented and evaluated by young people".

The MILDECA (Interministerial Mission for the Fight against Drugs and Addictive Behaviour), whose mission is to prepare the government plans to fight against drugs and drug addiction, specifically declined in the 2008-2011 plan prevention policy in schools of 1st and 2nd degrees (MILDECA, 2008). One of the main objectives is "to avoid early experiments with drugs and/or alcohol abuse and to combat attitudes that contribute to trivializing and accepting such behavior". The plan also emphasizes that reaching this aim "involves broadening the spectrum of preventive actions, traditionally confined to health education, other forms of intervention". Therefore we develop an alternate model of action.

\section{Aims and Methods}

The project is to educate young people about the dangers of addiction through scientific research based on the program "Apprentis Chercheurs" developed by the association l'Arbre des Connaissances

(http://www.arbre-des-connaissances-apsr.org). Founded in 2004 by scientific researchers at the University Institute of Hematology (University Paris-Diderot), l'Arbre des Connaissances is an association whose aims are to stimulate curiosity, investigation approach and critical mind of young people. For this purpose research laboratories are asked to welcome pairs of young (one in the $4^{\text {th }}$ year and one in the sixth year of high school), called the "Apprentis Chercheurs", who are tutored with senior researchers. These adolescents are trained to be critical through the experimental approach: they identify a scientific question with their tutor, plan and carry together experiences that will bring the answer. They work in the lab on Wednesday afternoon once or twice per month all along the school year. At the end of the scholar year, high school students prepare slide presentation, raising their scientific topic, questions, hypotheses and experimental results. Then, the "Apprentis Chercheurs" orally communicate their results to other students of their schools, their teachers, their parents and the research team in a peer to peer approach during a scientific conference organized within every participant research center. This formula works perfectly: since 2004, more than 1000 "Apprentis Chercheurs" were directly welcomed in 26 research centers in France, but allowing to much more pupils and family to get sensitized to scientific approach. Moreover, the association of scientists' l'Arbre des Connaissances was recognized for its work by winning the Diderot award in 2011, confirming the validity of the model.

"Apprentis Chercheurs" plan of action was initiated from the will of research scientists to open their own laboratories to generate interest in science of teenagers. Two other actions created by scientists emerged more recently in France. The program "Tous Chercheurs" proposes a model of scientific education for school students in Marseille. For three days, young pupils are welcomed in a dedicated lab in research institute, where they participate to a short research program (Hammond et al., 2010). Another action, called Science Academie was in- 
itiated by researchers of Ecole Normale Supérieure in Paris of Paris Montagne association

(http://www.paris-montagne.org/science-academie). It proposes to welcome high school students for 3 - 5 days in specific research laboratories or for discovery week of multi-disciplinay scientific conferences. Altogether, theses various actions allow crosstalks between science and society and permit for high school students to develop their way of thinking, useful for an active and creative citizenship.

In 2012, we decided to adapt the program "Apprentis Chercheurs" to sensitize young people to the deleterious effects of addictive drugs. According to National Research Council (National Research Council, 1996), the scientific literature contains the knowledge and the understanding of scientific concepts that are necessary for making informed decisions on personal and societal issues. In this context, our hypothesis is that performing experimentation showing the toxic potential and /or the addictive power of drugs using experimental models, either animal or not, would lead to modify their representations of the product and strengthen their awareness that the drug-related pleasure is associated with its harmfulness. Moreover, the duration of this program, all along the school year, would allow establishing a reliable link between the young and his (her) supervisor. Consequently, as the latter is a professional of the scientific research (researcher, engineer, $\mathrm{PhD}$ student, post- $\mathrm{PhD}$ student), their relationship is not be based on morality since the "Apprentis Chercheurs" share actual researches with the scientist and is not only listening the voice of the adult. The program is named MAAD, Mechanisms of Addiction to Alcohol and Drugs; in order to outspread the concept in the concerned schools and beyond we created a logo which is presented in Figure 1.

The MAAD program involves middle and high schools including the head masters, the teachers and the regional education authority. This is of crucial importance regarding the diffusion of the results. Indeed the "Apprentis Chercheurs" become new scientific intermediary asked to report their experience within their classes and their schools, but also within their families, and within a widened public, by being carriers of another vision of drugs.

\section{Results and Discussion}

For the first session held in 2012-2013, five expert laboratories dedicated to research on addiction (Table 1) agreed to participate to the MAAD program and welcomed 10 pair-workers, i.e. a total of 20 "Apprentis Chercheurs". These latter spent from 9 to 12 Wednesday afternoons in the lab according to their availability. They were completely integrated in the research team, they wear a lab coat and had their own lab book and directly participated to research programs on-going in the lab. Three programs were targeted on alcohol effect and the remaining two on cocaine (Table 1). "Apprentis Chercheurs" participated to and performed by themselves several experiments: implementation of dependence in animals through intra-venous self-administration (Skinner cage), behavioral experiments (rotarod, plus-maze, open-field), analysis of gene expression using polymerase chain reaction, electrophysiology with long-term potentiation (LPT) and depression (LTD) measurement, im-

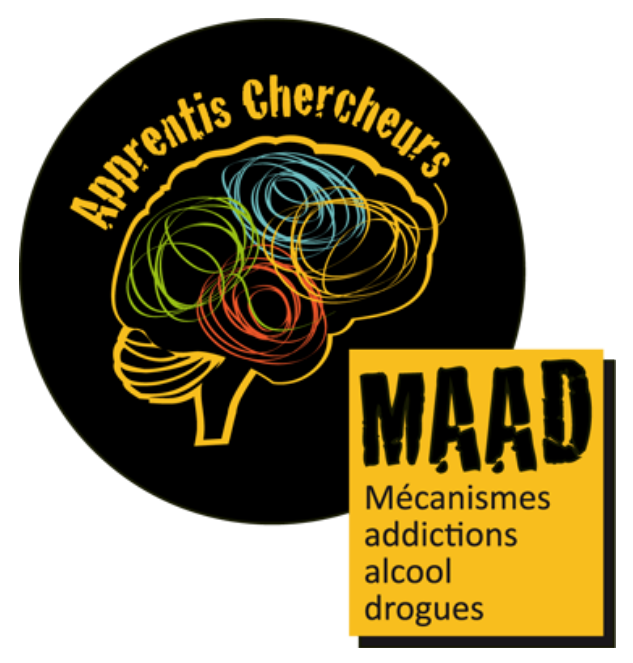

Figure 1. The MAAD logo. 
Table 1. Laboratories participating to the MAAD program in 2012-2013.

\begin{tabular}{cccc}
\hline & Laboratory & Location & Title of the MAAD Program \\
\hline Supervisor & Institute & Amiens & Effect of early alcohol exposure on memory in a mice model \\
M. Naassila & Inserm ERI24 & Marseille & Inactivation of sub-thalamic nucleus as a possible treatment \\
of alcoholism in rats
\end{tabular}

munohistochemistry... In most laboratories comparisons were done between "young" and "adult" animals. A short movie was shot in the respective labs and staged as a "NCIS ${ }^{\odot}$-like" session by a professional company (TerreTV, 2013).

At the end of the training, "Apprentis Chercheurs" were asked to present their results. For this purpose, conferences were organized in each research centers in early June 2013. Attendees were their friends, their school co-workers, their family, their teachers etc.; their number range from 70 to 100 from a center to another. Each working pair communicated their results using a slide show prepared in collaboration with the supervisor. A lecture given by a senior researcher expert in addiction completed the program. At the end of the conference, a get together party without alcoholic beverages was hold to favor discussion between all the participants. Following this conference most of the teachers organized a second presentation inside their school in order to address a general discussion on addiction with all the pupils. On the whole, around 400 pupils attended to the congress, and 200 more were present when the MAAD program was presented in the University Sorbonne in Paris during the 2013 French science week.

A second session of the MAAD program, still funded by the MILDECA, was performed in 2013-2014. Nine labs participated and 33 pupils were welcomed. They worked on alcohol, cocaine, cannabis, amphetamine and nicotine addiction in different animal models; they studied the role of genetic variant, the impact of enriched environment, the role of sub-thalamic nucleus injury, the memory defect induced by alcohol, the alteration of dopaminergic network and others topics using several sophisticated technics currently run in research labs. A movie was shot (TerreTV, 2014); conferences were held in June 2014 and about 400 adolescents attended to the congress. Moreover, each pair of Apprentice prepared a poster of their work; a specimen of each poster was send to all the schools participating to the program. They will be exhibited in the school halls in order to prompt discussion on this topic in the classroom but also within the playground.

The third session is scheduled to start in September 2014. Twelve labs will participate and 36 Apprentices will be welcomed.

Although behavior change against drug of abuse in adolescents is the ultimate end of our action, it cannot be evaluated by now. However all the Apprentices claimed that through this program they discovered that becoming addict is not only related to a psychological weakness but also to a biological sensitivity; they learned that drugs of abuse are specifically dangerous on the developing brain; finally they understand that withdrawing from an addiction is not based on the willpower only since the brain network has been injured by the drugs.

\section{Conclusion}

The MAAD program is an original way to sensitize teenagers to the addiction-related harm. Scientific education appears to be a convenient method to change the representation of drugs in adolescents.

\section{Acknowledgements}

The authors thank: all the lab teams who welcome the Apprentis Chercheurs and who are involved with enthusiasm in this program; Mrs Florence Lafay-Dufour from the MILDECA for her constant help in the development of this program; Mrs Daniele Jourdain-Menninger, president of the MILDECA for the financial support. 


\section{Funding}

The MAAD program is funded by the MILDECA (Mission Interministérielle de Lutte contre les Drogues et les Conduites Addictives) and supported by the Inserm.

\section{References}

Dawson, D. A., Goldstein, R. B., Chou, S. P., Ruan, W. J., \& Grant, B. F. (2008). Age at First Drink and the First Incidence of Adult-Onset DSM-IV Alcohol Use Disorders. Alcoholism: Clinical and Experimental Research, 32, 2149-2160. http://dx.doi.org/10.1111/j.1530-0277.2008.00806.x

DeWit, D. J., Adlaf, E. M., Offord, D. R., \& Ogborne, A. C. (2000). Age at First Alcohol Use: A Risk Factor for the Development of Alcohol Disorders. The American Journal of Psychiatry, 157, 745-750. http://dx.doi.org/10.1176/appi.ajp.157.5.745

ESPAD (2007).The European School Survey Project on Alcohol and Other Drugs. www.espad.org

Hammond, C., Karlin, D., \& Thimonier, J. (2010). Creative Research Science Experiences for High School Students. PLoS Biology, 8, e1000447. http://dx.doi.org/10.1371/journal.pbio.1000447

Hingson, R. W., Heeren, T., \& Winter, M. R. (2006). Age at Drinking Onset and Alcohol Dependence: Age at Onset, Duration, and Severity. Archives of Pediatrics and Adolescent Medicine, 160, 739-746. http://dx.doi.org/10.1001/archpedi.160.7.739

JOCE (2001). L 161/40 FR. Journal officiel des Communautés européennes. http://www.fbvs.be/files/pdf/recommandations_Conseil_5_06_2001_C458_FR.pdf

Legleye, S., Spilka, S., Le Nézet, O., \& Laffiteau, C. (2009). Les drogues à 17 ans—Résultats de l'enquête ESCAPAD 2008. Tendances 66, 1-6. http://www.ofdt.fr/ofdtdev/live/publi/tend/tend66.html

MILDECA (2008). Plan gouvernemental de lutte contre les drogues et les toxicomanies 2008-2011.

National Research Council (1996) National Science Education Standards. Washington, DC: The National Academies Press.

Spilka, S., \& Le Nézet, O. (2011). Premiers résultats du volet français de l'enquête European School survey Project on Alcohol and Other Drugs (ESPAD). http://www.ofdt.fr/BDD/publications/docs/eisxsss5.pdf

Spilka, S., \& Le Nézet, O. (2012). Les drogues à 17 ans: Premiers résultats de l'enquête ESCAPAD 2011. Tendances 79, 1-4. http://www.ofdt.fr/ofdtdev/live/publi/tend/tend79.html

TerreTV (2013). http://www.terre.tv/fr/5350_des-apprentis-chercheurs-completement-maad

TerreTV (2014). http://www.terre.tv/fr/5886 les-apprentis-chercheurs-maad 
Scientific Research Publishing (SCIRP) is one of the largest Open Access journal publishers. It is currently publishing more than 200 open access, online, peer-reviewed journals covering a wide range of academic disciplines. SCIRP serves the worldwide academic communities and contributes to the progress and application of science with its publication.

Other selected journals from SCIRP are listed as below. Submit your manuscript to us via either submit@scirp.org or Online Submission Portal.
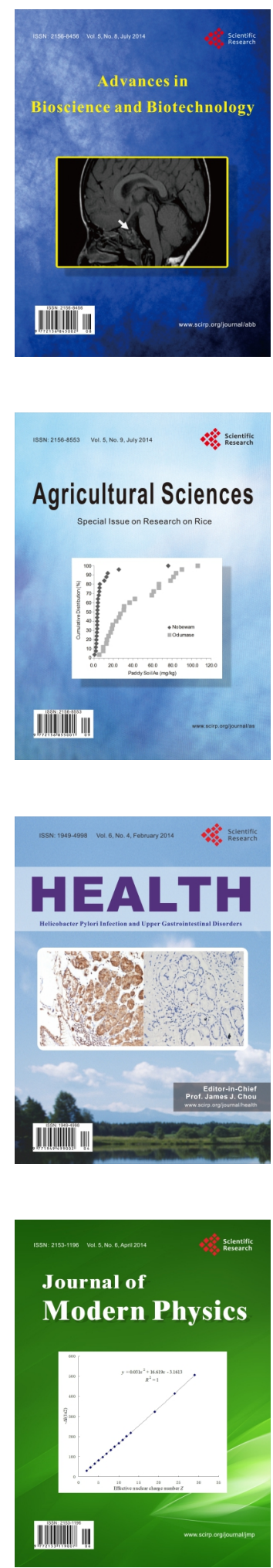
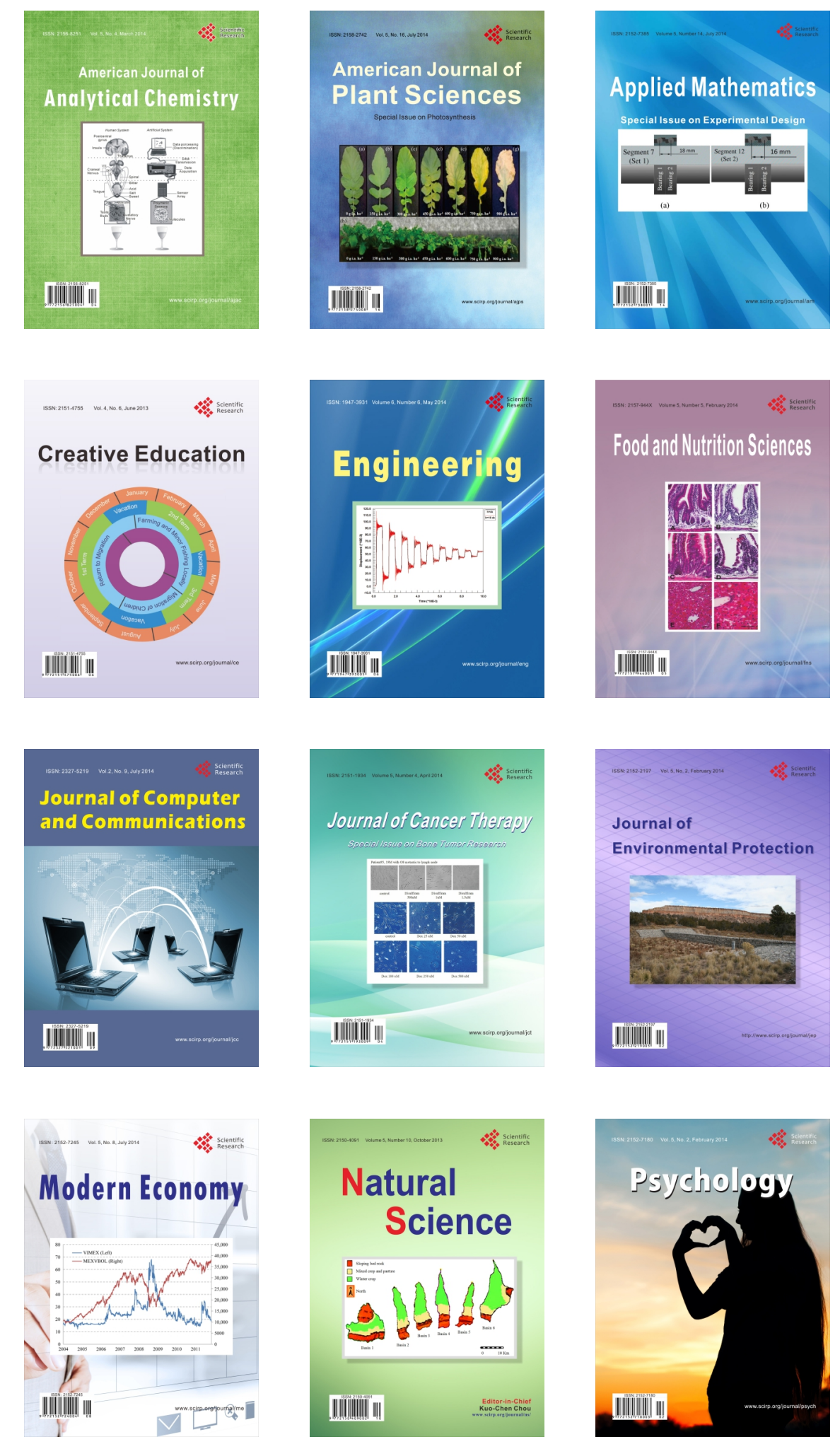